\title{
TEACHING LISTENING USING DUOLINGO APPLICATION
}

\author{
Lidya Maldini Putri ${ }^{1}$, Aulia Islamiati ${ }^{2}$ \\ ${ }^{1}$ IKIP Siliwangi \\ ${ }^{2}$ IKIP Siliwangi \\ ${ }^{1}$ email-lidyamaldini777@gmail.com, ${ }^{2}$ email-auliaislamiatisakinah@gmail.com
}

\begin{abstract}
Listening is one of the language skills that quite difficult to master. Listening to more attention and more concentration is needed than any other skill. Listening is different with hearing. Hearing refers to the ear that the voice enters. Physically process, depending on whether they have a hearing problem, which happens automatically. While listening not only give an attention to the story, but the way it is told, language, intonation, voice, and body language. The objective of this study entitled "Teaching Listening Using Duolingo Application" was to reveal whether or not using an application called Duolingo in English learning significantly improves students' listening skills. This research used pre-experimental design and quantitative research method. This study involves 799 consisting of 24 classes in SMKN 2 Karawang and the author takes only one class of 36 students in X-Tata Boga 3 Class. Furthermore, the data taken from pretest and posttest results to find out whether using Duolingo apps improves students' listening skills. The collected data were analyzed using SPSS 24 version. This study found that test of normality consist the data of pretest is $(0.076)$ and the data of posttest is $(0.200)$ in 33 samples. In addition the value of Sig. (2-tailed) 0.000 because of the value of the Sig value. (2-tailed) $<0.005$ it can be concluded that using of Duolingo Applications can improve students' listening skills and also able to make the teaching list motivate students in learning English.
\end{abstract}

Keywords: Teaching, Listening, Duolingo Application

\section{INTRODUCTION}

Listening is a language skill that is quite difficult to master. Listening requires more attention and concentration than any other skill. According to Nation and Newton, (2009: 52) "Listening is the first beginning of a natural (oral) speech; developed in the early stages of language and a person's first language (and other naturalistic acquisitions of languages) that depend on hearing". In other words, listening is not the same as hearing. Hearing refers to the ear that the voice enters. Physically processed that happens automatically. While listening not only pay attention to the story, but how the story is told, language, intonation, voice, and body language. In other words, listening should be aware of both verbal and non-verbal messages. Exercise is very important so that students are able to master the ability to listen, of course, by using methods or media that can attract students' interest.

In the mastery of ability consists of 4 elements of listening, writing, speaking, and reading. In this case, it can be seen that the writers more describes the ability to listening in the learning process. This is stated by Harmer (2007: 133) "Listening is also good for the pronunciation of students, because they understand what they are, and emphasize and hear individual words and words mingling in a connected speech. Listening to texts is a good pronunciation model, in other words, and the more students listen, the better they get, not just in understanding the words, but also to speak for themselves".

Using media-based methods or technologies that are aligned with today's modern technology (e-learning). According to Kopecký, K (2006: 125) "e-Learning can be understood in connection with multimedia support for an educational process with using modern information 
and communication technologies, which are usually categorized or implemented through a computer network." In this case, the writer using Duolingo Free Language Learning Application as a media of learning. Duolingo as a new e-learning education portal. Duolingo is a free language learning app created by Luis von Ahn and Severin Hacker. Duolingo is a learning site that learns the language for free. Languages that can be learned not only in English, also like Spanish, French, South Korean, Italian, Germany, Portuguese and more of 9 others language. Duolingo has a good learning strategy because it greatly motivates learning systems using game mechanics strategies to create guard incentives for students to learn. Built up very similar to computer games where participants have to pass a certain level. A student passes through the language tree level. The next lesson can be opened after the learner has mastered the previous material. Users can complete various types of exercises including many options, writing, listening and also speaking through a microphone. Duolingo uses exercises and recurring exercises in the lesson. Duolingo deliberately brings the concept of "play and learn" to be able to create a comfortable and enjoyable learning atmosphere.

\section{METHOD}

This research uses quantitative research design because there are or related to data collection using numerical and statistic. As pointed out by Creswell (2009: 22-23) "Quantitative research is a container to test the theory objectively with the relationship between variables examined first". The writer research used Pre-experimental design, which used the one group of pretestposttest design. The characteristics of pre-experimental design are this design may have pretest and posttest, without a control group . According to Best and Khan in Tavakoli (2012: 485) "The pre-experimental design is not really considering the experimental model as they do not take into account extraneous variables that may have affected the outcome. Thus, the internal validity of such designs is also questionable".

The population of this research was the first grades students of SMK 2 Karawang academic years 2017/2018. Thus the total of population of 10 grades which consist, 24 class, consisted of 799 students. The writers will use purposive sampling in which the research only choose one class. The class chosen by the writer is X TataBoga-3, the number of samples is 36 students who take as the participants of the research.

To collect data, the writer uses the instrument. An instrument that used was pretest and posttest. The writer used pre-test and post-test to get the data. The students listened carefully to the Duolingo Application, and they had to write the sentences that are in Duolingo App said in a worksheet. The pretest was used to find the students' ability or achievement before treatment students given several questions consists of 20 item. Before Pretest begins, students directed by the author to listen carefully and write what they hear in the worksheet. Than for posttest, the questions used in posttest are the same as those used in protest. Posttest is given in order to know the students' achievement in listening mastery using Duolingo Application. After the data gain from the pre-tests and post-tests, then it will be analyzed by using SPSS 24 . To analyze the data using SPSS the writer calculated: Normality Test, Homogeneity Test, T-Test.

\section{RESULTS AND DISCUSSION}

\section{Results}

The data tabulation of teaching listening using Duolingo Application is based on the calculation of pretest and posttest scores. 
Table 4.1The Students Scores

\begin{tabular}{|c|c|c|}
\hline Name & Pretest & Posttest \\
\hline student 1 & 50 & 100 \\
\hline student 2 & 45 & 70 \\
\hline student 3 & 50 & 85 \\
\hline student 4 & 60 & 95 \\
\hline student 5 & 50 & 85 \\
\hline student 6 & 65 & 90 \\
\hline student 7 & 55 & 90 \\
\hline student 8 & 45 & 75 \\
\hline student 9 & 65 & 95 \\
\hline student 10 & 40 & 65 \\
\hline student 11 & 35 & 60 \\
\hline student 12 & 40 & 65 \\
\hline student 13 & 45 & 75 \\
\hline student 14 & 55 & 85 \\
\hline student 15 & 45 & 80 \\
\hline student 16 & 45 & 75 \\
\hline student 17 & 40 & 70 \\
\hline student 18 & 55 & 80 \\
\hline student 19 & 50 & 80 \\
\hline student 20 & 45 & 85 \\
\hline student 21 & 35 & 60 \\
\hline student 22 & 55 & 75 \\
\hline student 23 & 60 & 95 \\
\hline student 24 & 50 & 80 \\
\hline student 25 & 40 & 70 \\
\hline student 26 & 45 & 70 \\
\hline student 27 & 55 & 90 \\
\hline student 28 & 35 & 65 \\
\hline student 29 & 40 & 70 \\
\hline student 30 & 45 & 80 \\
\hline student 31 & 50 & 75 \\
\hline student 32 & 50 & 80 \\
\hline student 33 & 55 & 75 \\
\hline SUM $\left(\sum\right)$ & 1595 & 2590 \\
\hline MEAN & 48.33 & 78.48 \\
\hline
\end{tabular}

Based on the table above, the result of pretest showed that the highest is 65 and the lowest score is 35 . For the posttest showed that the highest score is 100 and the lowest is 60 . While the total Sum $\left(\sum\right)$ for pretest is 1595 and for post test score 2590 and the Mean value of pre test score is 48.33 while the Mean post test score is 78.48

Analysis Data 
After get the result of pretest and posttest, the writer used one Shapiro-Wilk sample to test the normality of the regression model using SPSS 24.0 Version with significant level 0.05. The results can be seen below:

Table 4.2 Test of Normality

\begin{tabular}{|c|c|c|c|c|c|c|}
\hline \multicolumn{7}{|c|}{ Tests of Normality } \\
\hline & \multicolumn{3}{|c|}{ Kolmogorov-Smirnov $^{\mathrm{a}}$} & \multicolumn{3}{|c|}{ Shapiro-Wilk } \\
\hline & Statistic & Df & Sig. & Statistic & df & Sig. \\
\hline Pretest & .145 & 33 & .076 & .952 & 33 & .149 \\
\hline Posttest & .115 & 33 & $.200^{*}$ & .967 & 33 & .406 \\
\hline
\end{tabular}

Based on table 4.1 the results above, because the number of samples more than 30 students then the writers use Kolmogorov-Smirnova. The result of pretest (0.076) and posttest (0.200), because the result $>0,05$ can then be concluded to be normally distributed.

After knowing the result of normality test, the writers look for result from Test of Homogeneity. Homogeneity tests are used to determine different population or samples having the same variant or not. Homogeneity test itself is usually done using SPSS 24.0 Version to know Test of Homogeneity Variances with sig. value 0.05 . The result can be seen as follow:

Table 4.3Test of Homogeneity

\begin{tabular}{lccc}
\multicolumn{4}{l}{ Test of Homogeneity of Variances } \\
\multicolumn{4}{l}{ PRETEST DAN POSTTEST } \\
\hline $\begin{array}{l}\text { Levene } \\
\text { Statistic }\end{array}$ & df1 & df2 & Sig. \\
\hline 2.286 & 1 & 64 & .135
\end{tabular}

Based on the table above can be seen that, the value of significance for the research teaching listening using Duolingo App $=0.135$. From these results it is known that sig. or P-value is higher than $0.05(0.135>0.05)$, which means $\mathrm{H} 0$ is accepted while Ha is rejected. It can be concluded that teaching listening using Duolingo App method for the sample (X-TB 3 class) has the same variant.

For the last, the writers looking for Paired samples T-test using SPSS 24.0 Version using Paired Sample T-test with sig. level 0.05 . The results are described in the following table:

Table 4.4 Paired samples T-test

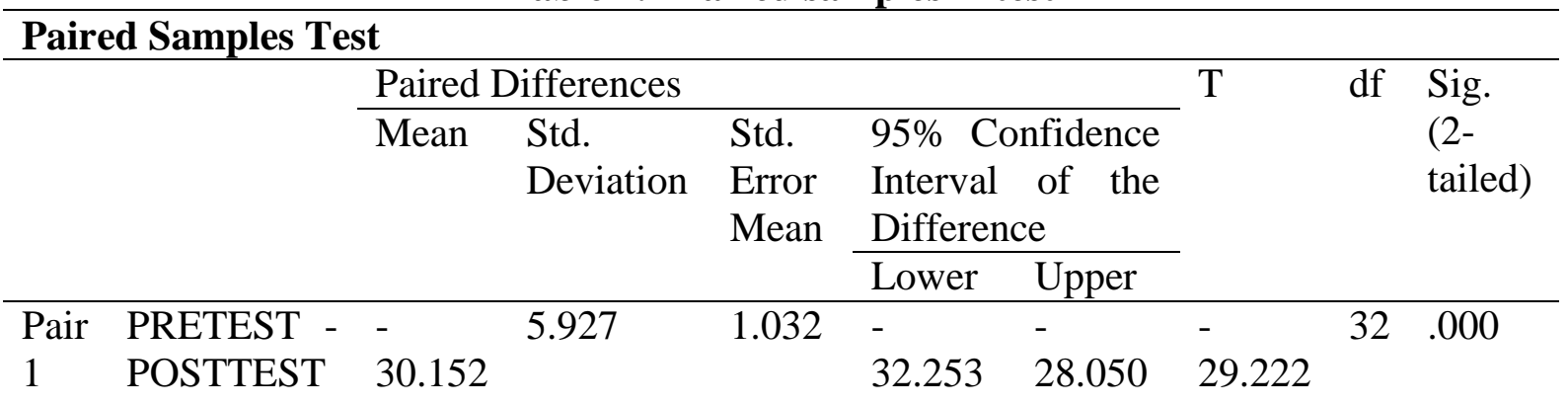

Based on table 4.3 the result above It appears that the t-table is $(-29.222)$ with a probability value (Sig. 2 tailed) 0,000 . Due to the probability of $0.000<0.05$, then $\mathrm{H} 0$ is rejected, which 
means pretest and posttest are not the same or real different. In output SPSS 24.0 there is also a mean difference of (30.152) that is the difference between pretest and posttest.

\section{Discussion}

Based on table 4.4. (2-tailed) $0.000<0.005$ it can be concluded that using of Duolingo Applications can improve students' listening skills. The result show there are significant differences between pretest and posttest. In fact, using e-Learning, in this case, is use Duolingo Application for teaching English is a good way to improve students' listening skill. It supports by Rossenberg (2006: 72) e-Learning is the use of Internet technology to create and deliver a learning environment that can include a variety of instructions and sources of information and solutions, aimed at improving individual and organizational performance. As mentioned above, e-Learning is an unlimited medium. As we know the internet as a major factor has a wide range that can be used anytime and anywhere. These results are in line with two previous studies conducted by Laila Mahmudah (2016), Pilar Munday (2016) that using Duolingo Application can improve students' listening skills better.

\section{CONCLUSION}

Based on the previous discussions, the writer gives some general conclusions as follow: The Teaching listening to know listening student ability before using Duolingo Application and after using Duolingo Application. In this research, the writer uses a quantitative method and research design used pre-experimental. The instrument of the research is pretest and posttest which consisted of 20 item things at school in an essay. After analyzing the writer then calculate that sig. the data of pretest is $(0.076)$ and sig. for the posttest is $(0.200)$ in 33 samples. Minimum is the value of the lowest for pretest is 35,00 and for posttest is 60,00 . The maximum is the highest value for pretest is 65,00 and for posttest is 100,00 . In addition the result OF value of Sig. (2-tailed) 0.000 because of the value of the Sig value. (2-tailed) $<0.005$ it can be concluded that using of Duolingo Applications can improve students' listening skills and also able to make the teaching list motivate students in learning English.

\section{ACKNOWLEDGMENTS}

Alhamdulillahirobbil'alamin, praise to Allah SWT who has enabled the writers to finish thisresearch paper. Peace and salutations are always for Rasullulah SAW. During the paper thewriter obtained a lot of help, suggestions, and motivations from many people. For that reason, the writer would like to express his gratitude to:

1. Dr.H. Heris Hendriana, M.Pd. as the Head of IKIP Siliwangi;

2. Dr.Irma Savitri Sadikin, M.Pd. as the Head of English Education Study Program;

3. Dr.Irma Savitri Sadikin, M.Pd as the first supervisor,

4. Trisnendri Syahrizal, S.Pd, M.Hum as the second supervisor

5. All lectures and staff of English Education Study Program of IKIP Siliwangi Bandung.

6. Our beloved parents who had given a prayer, help, and support.

7. Our beloved friends Besties.

8. Students of KR 2014 class of English Education Study Program who had given and spirit and cooperation;

Finally, thanks are due to all people who had prayed and supported the writing who can not be mentioned one by one. May Allah bless them all. 


\section{REFERENCES}

Creswell, J.W. (2006) Research Design: Qualitative, Quantitative, And Mixed Methods Approach. United States Of America: SAGE Publications, Inc.

Harmer, J. (2007) How To Teach English. China: Pearson Education Company.

KOPECKÝ, K. (2006) E-Learning (Nejen) Pro Pedagogy. Olomouc: Hanex.

Nation.I.S.P, \& Newton, J. (2009) Teaching ESL/EFL Listening And Speaking: ESL Applied Linguistics Professional Series. New York: Routledge.

Rossenberg,J. M. (2006) Beyond E-Learning: Approaches And Technologies To Enhance Organizational Knowledge, Learning, And Performance. United States Of America: John Wiley \& Sons, Inc.

Tavakoli, H. (2012) A Dictionary Of Research Methodology And Statistics In Applied Linguistics. Rahmana Press. 